Original Article

\title{
Durability and performance of CGO barriers and LSCF cathode deposited by spray-pyrolysis
}

\author{
L. dos Santos-Gómez ${ }^{\mathrm{a}}$, J. Hurtado ${ }^{\mathrm{b}}$, J.M. Porras-Vázquez ${ }^{\mathrm{a}}$, E.R. Losilla ${ }^{\mathrm{a}}$, D. Marrero-López ${ }^{\mathrm{b}, *}$ \\ a Universidad de Málaga, Departamento de Química Inorgánica, 29071, Málaga, Spain \\ b Universidad de Málaga, Departamento de Física Aplicada I, Laboratorio de Materiales y Superficie, 29071, Málaga, Spain
}

\section{A R T I C L E I N F O}

\section{Keywords:}

Solid oxide fuel cells

$\mathrm{La}_{0.6} \mathrm{Sr}_{0.4} \mathrm{Co}_{0.2} \mathrm{Fe}_{0.8} \mathrm{O}_{3-\delta}$

$\mathrm{Zr}_{0.84} \mathrm{Y}_{0.16} \mathrm{O}_{1.92}$

$\mathrm{CeO}_{2}$

Spray-pyrolysis

\begin{abstract}
A B S T R A C T
$\mathrm{Ce}_{0.9} \mathrm{Gd}_{0.1} \mathrm{O}_{1.95}$ (CGO) protective layers are prepared by two different methods to prevent the reaction between the $\mathrm{Zr}_{0.84} \mathrm{Y}_{0.16} \mathrm{O}_{1.92}$ (YSZ) electrolyte and the $\mathrm{La}_{0.6} \mathrm{Sr}_{0.4} \mathrm{Co}_{0.2} \mathrm{Fe}_{0.8} \mathrm{O}_{3-\delta}$ (LSCF) cathode. In the first method, the CGO layers are deposited by an airbrushing technique from an ink containing CGO particles without and with cobalt as sintering aids. The second strategy consists in preparing both a dense CGO barrier layer and a porous LSCF cathode by spray-pyrolysis deposition, in order to further reduce the fabrication temperature and minimize the reaction between the cell components. The samples prepared by spray-pyrolysis exhibit better performance and durability than those obtained by conventional sintering methods. The results suggest that the interfacial reactivity between YSZ and LSCF as well as the Sr-enrichment at the cathode surface can be avoided by using low-temperature fabrication methods and by operating at temperatures lower than $650{ }^{\circ} \mathrm{C}$.
\end{abstract}

\section{Introduction}

Solid Oxide Fuel Cells are considered as one of the most efficient technologies for electrical power generation. However, their high operating temperatures involve a number of disadvantages, regarding the durability and potential application of these devices [1-3]. In this context, the main research trends in SOFCs are focused on reducing their operation temperature.

Nowadays, it is considered that the SOFC performance is mainly limited by the cathode polarization resistance. The most commonly used cathode material, $\mathrm{La}_{0.8} \mathrm{Sr}_{0.2} \mathrm{MnO}_{3-\delta}$ (LSM), is physically and chemically compatible with the standard $\mathrm{Zr}_{0.84} \mathrm{Y}_{0.16} \mathrm{O}_{1.92}$ (YSZ) electrolyte [4]. However, it exhibits low catalytic activity for oxygen reduction reactions at low operating temperatures. More efficient cathodes could be used, such as $\mathrm{La}_{0.6} \mathrm{Sr}_{0.4} \mathrm{Co}_{0.2} \mathrm{Fe}_{0.8} \mathrm{O}_{3-\delta}$ (LSCF) [5-7]. Unfortunately, LSCF is well known to strongly react with YSZ, forming insulating secondary phases like $\mathrm{SrZrO}_{3}$ and $\mathrm{La}_{2} \mathrm{Zr}_{2} \mathrm{O}_{7}[8,9]$. The formation of these low conducting phases at the cathode/electrolyte interface occurs during the SOFC fabrication and operation, resulting in a drastic loss of performance over time [10].

A possible solution to avoid the reaction between YSZ and LSCF is the introduction of a diffusion barrier layer of $\mathrm{Ce}_{0.9} \mathrm{Gd}_{0.1} \mathrm{O}_{1.95}$ (CGO) between both materials [11-14]. Such interlayer needs to be sufficiently thin and dense to avoid the introduction of additional ohmic resistance. The screen-printing is the most commonly used method to prepare the CGO interlayer. In this case, the sintering temperature is a crucial factor to ensure an adequate adhesion with the YSZ electrolyte without loss of performance. In particular, a low sintering temperature produces a porous interlayer with high electrical resistance. Moreover, recent studies have reported that Sr species from LSCF easily diffuse on the porous surface of the CGO grains and react with YSZ [15-17]. Sr diffusion across the grain boundary of dense CGO layers has been also observed, although the diffusion rate is much slower. In contrast, high sintering temperatures result in a dense CGO layer but also interdifussion of Ce and $\mathrm{Zr}$, leading to the formation of a solid solution $\left(\mathrm{Zr}_{1-\mathrm{x}} \mathrm{Ce}_{\mathrm{x}}\right)$ $\mathrm{O}_{2-\delta}$ with lower conductivity than YSZ [18].

The use of sintering aids, such as Co, $\mathrm{Zn}$ and $\mathrm{Li}$, is an alternative strategy to improve the densification of CGO at a lower sintering temperature. The effect of these additives on the densification and transport properties of CGO ceramic pellets has been widely investigated in different studies [19-21]. However, only few works have reported the influence of these additives on the performance of CGO interlayers $[22,23]$.

Alternative physical and chemical deposition methods have been employed to fabricate dense CGO interlayers, including magnetronsputtering [24-27], pulsed laser deposition [28] and spin-coating [29]. In general, most of these methods are usually expensive or less attractive from an industrial point of view as they require multiple steps in

\footnotetext{
* Corresponding author. Present address: Dpto. de Física Aplicada I, Laboratorio de Materiales y Superficies, Facultad de Ciencias, Campus de Teatinos, Universidad de Málaga, 29071Málaga, Spain.

E-mail address: marrero@uma.es (D. Marrero-López).
} 
the preparation of the cell. In contrast, spray-pyrolysis is an economic and industrially scalable technique to prepare thin films materials, which has been widely used to obtain different SOFC components [30-32]. The morphology of the films, e.g. their thickness and porosity, can be easily tailored by varying the deposition parameters, such as temperature and deposition time [33,34]. Several studies have reported the preparation of CGO interlayers by spray-pyrolysis [35-37]; however, the LSCF cathode is commonly deposited by traditional screenprinting at high sintering temperatures, favoring the cation interdiffusion between the materials layers.

In the present study, both the CGO interlayer and the LSCF cathode are prepared by spray-pyrolysis deposition to reduce the fabrication temperature at only $800{ }^{\circ} \mathrm{C}$, and minimize the reaction between the cell components. For the sake of comparison, the CGO and LSCF layers were prepared by conventional deposition methods, airbrushing and screenprinting. The microstructure and polarization resistance evolution of the symmetrical cells are investigated as a function of the annealing time. Moreover, the results are compared with those obtained for cells without CGO interlayer.

\section{Experimental}

\subsection{Materials preparation}

$\mathrm{Zr}_{0.84} \mathrm{Y}_{0.16} \mathrm{O}_{1.92}$ (YSZ) substrates were prepared by pressing commercial powders (Tosoh) into disks of 13 and $1.5 \mathrm{~mm}$ of diameter and thickness, respectively, followed by sintering at $1400^{\circ} \mathrm{C}$ for $4 \mathrm{~h}$ in air (relative density $>95 \%$ ).

For the preparation of the $\mathrm{Ce}_{0.9} \mathrm{Gd}_{0.1} \mathrm{O}_{1.95}$ (CGO) interlayers by airbrush deposition, an ink was obtained by mixing $1 \mathrm{~g}$ of CGO powder (particle diameter of $50 \mathrm{~nm}$, Rhodia), $1 \mathrm{~g}$ of Decoflux ${ }^{\mathrm{TM}}$ as organic binder and $10 \mathrm{ml}$ of ethanol as solvent. A suspension of particles was obtained after ultrasonic agitation. The resulting ink was deposited symmetrically onto the YSZ pellets by using a commercial airbrush; followed by sintering at $1100^{\circ} \mathrm{C}$ for $2 \mathrm{~h}$.

In order to improve the densification of the CGO layer, $2 \mathrm{~mol} . \%$ of $\mathrm{Co}\left(\mathrm{NO}_{3}\right)_{2} \cdot 6 \mathrm{H}_{2} \mathrm{O}$ was added to the starting CGO powders and the sintering temperature was reduced to $1000^{\circ} \mathrm{C}$ for $2 \mathrm{~h}$. Notice that this is the optimum Co-content to obtain dense CGO pellets at $1000^{\circ} \mathrm{C}$ without altering significantly their transport properties [19]. The porosity of the CGO layers was estimated from their thickness by electron microscopy and the deposited mass by the weight difference between the pellets with and without CGO layer. $\mathrm{La}_{0.6} \mathrm{Sr}_{0.4} \mathrm{Co}_{0.2} \mathrm{Fe}_{0.8} \mathrm{O}_{3-8}$ (LSCF) powder cathode was obtained by a freeze-drying precursor method as described in detail elsewhere $[38,39]$. An ink was prepared by mixing the powders with Decoflux and then deposited onto the CGO interlayer by screen-printing and sintering at $1000^{\circ} \mathrm{C}$ for $2 \mathrm{~h}$.

For the preparation of the CGO layers by spray-pyrolysis; an aqueous precursor solution with a concentration $0.025 \mathrm{~mol} \mathrm{~L}^{-1}$ was obtained from $\mathrm{Ce}\left(\mathrm{NO}_{3}\right)_{3} \cdot 6 \mathrm{H}_{2} \mathrm{O}, \mathrm{Gd}\left(\mathrm{NO}_{3}\right)_{3} \cdot 6 \mathrm{H}_{2} \mathrm{O}(>99 \%)$ and citric acid $\left(0.0125 \mathrm{~mol} \mathrm{~L}^{-1}\right)$ as chelating agent; all of them supplied by SigmaAldrich. The precursor solution was sprayed symmetrically onto the YSZ pellets at $400{ }^{\circ} \mathrm{C}$ with a solution flow rate of $20 \mathrm{~mL} \mathrm{~h}^{-1}$ at a pressure of 2 bar. The nozzle-substrate distance and deposition time were of $20 \mathrm{~cm}$ and $1 \mathrm{~h}$, respectively. Afterwards, the CGO layers were treated at $650^{\circ} \mathrm{C}$ for $2 \mathrm{~h}$ to remove the residual species. Finally, the LSCF cathode was deposited by spray-pyrolysis at $250{ }^{\circ} \mathrm{C}$ for $1 \mathrm{~h}$, following the procedure described in [40]. The deposition parameters were optimized in order to obtain porous LSCF layers of $\sim 3 \mu \mathrm{m}$ thickness. Notice that the electrode thickness could be tailored by modifying the deposition parameters such as temperature and time. The symmetrical cells were finally treated at $800{ }^{\circ} \mathrm{C}$ for $2 \mathrm{~h}$ to improve the crystallization.

\subsection{Materials characterization}

The materials were analyzed by X-ray powder diffraction (XRD) with a PANalytical Empyrean diffractometer and $\mathrm{CuK}_{\alpha 1,2}$ radiation. The phase identification and structural analysis were performed by using the X'Pert HighScore Plus and GSAS software [41,42].

The chemical compatibility between YSZ and CGO was reexamined because the co-sintering temperature of CGO and YSZ layers varies in the literature in a broad range from 1100 to $1500{ }^{\circ} \mathrm{C}$ [43]. For this purpose, YSZ and CGO powders (weight ratio of 1:1 and average particle size of $100 \mathrm{~nm}$ ) were intimately mixed in a ball-mill machine at $150 \mathrm{rpm}$ for $1 \mathrm{~h}$. The resulting mixture was calcined in a furnace between 800 and $1400^{\circ} \mathrm{C}$ for $24 \mathrm{~h}$ and then analyzed by the XRD-Rietveld method [44].

The microstructure and cation interdiffusion at the LSCF/CGO/YSZ interfaces were analyzed by Field Emission SEM (FEI, Helios Nanolab 650) coupled with energy-dispersive X-ray microanalysis (EDX, Oxford instruments).

The polarization resistance was determined by impedance spectroscopy in symmetrical cells using a Solartron 1260 FRA. The data were acquired in the frequency range of $0.01-10^{6} \mathrm{~Hz}$ with $0.1 \mathrm{~V}$ ac amplitude. Platinum paste and meshes were used as current collectors. The measurements were initially performed on cooling process in the temperature range of $300-800^{\circ} \mathrm{C}$ and then at isothermal temperatures of 650 and $800^{\circ} \mathrm{C}$ for $300 \mathrm{~h}$ at open circuit voltage under air atmosphere. The spectra were analyzed by equivalent circuit models with the ZView software [45].

\section{Results and discussion}

\subsection{Phase analysis and compatibility}

Fig. 1a shows the XRD patterns of the CGO-YSZ powder mixture after calcining at different temperatures between 800 and $1400{ }^{\circ} \mathrm{C}$ for $24 \mathrm{~h}$. No evidence of reaction is observed at temperatures below $1000{ }^{\circ} \mathrm{C}$, and both the cells parameters and phase fractions remain similar to the pristine materials (Fig. 1b). However, reactivity is clearly observed after calcining at only $1100^{\circ} \mathrm{C}$, appearing new diffraction peaks associated with the formation of a new fluorite related phase. On the other hand, the diffraction peak intensity of the CGO decreases, confirming a significant cation interdiffusion between the materials. The XRD patterns are refined by the Rietveld method by considering different fluorite-type phases. In a first stage, the unit cell parameter and weight fraction of YSZ increase with the firing temperature, indicating that the $\mathrm{Ce}^{4+}$ is mainly incorporated in the YSZ lattice (Fig. 1b). Simultaneously, the weight fraction of CGO decreases with the firing temperature, and at last two reaction products with different $\mathrm{Zr}$ :Ce ratio appear between 1200 and $1300^{\circ} \mathrm{C}$. Finally, only a fluoritetype phase is observed above $1400^{\circ} \mathrm{C}$, confirming the complete reaction between the materials and the formation of a solid solution.

It is evident that the reaction between CGO and YSZ is favoured in an intimate mixture of submicrometric particles after long term annealing due to high contact area between the materials. However, the present results confirm a significant cation interdiffusion between YSZ and CGO at temperatures as low as $1100^{\circ} \mathrm{C}$, which would negatively affect the transport properties of a SOFC [18]. Thus, the co-sintering of YSZ and CGO needs to be limited at temperatures lower than $1100^{\circ} \mathrm{C}$.

Bearing in mind these results a stronger chemical reaction between YSZ and nanocrystalline CGO films is expected. For this reason, the compatibility between spray-pyrolysis CGO films and YSZ substrate was investigated. Fig. 1c shows the evolution of the XRD patterns after firing in a furnace between 600 and $1400{ }^{\circ} \mathrm{C}$ for $24 \mathrm{~h}$. The intensity of the XRD peaks of CGO increases gradually with the firing temperature due to the improved crystallinity and the grain size growth; however, no appreciable bulk reactivity is detected up to $1100^{\circ} \mathrm{C}$. Moreover, the unit cell parameters remain almost constant with the temperature, suggesting that the reaction is limited at the CGO/YSZ interface (Fig. 1d). Above $1100{ }^{\circ} \mathrm{C}$, the diffractions peaks become asymmetric due to the interdiffusion of cations between the material layers. Three different 

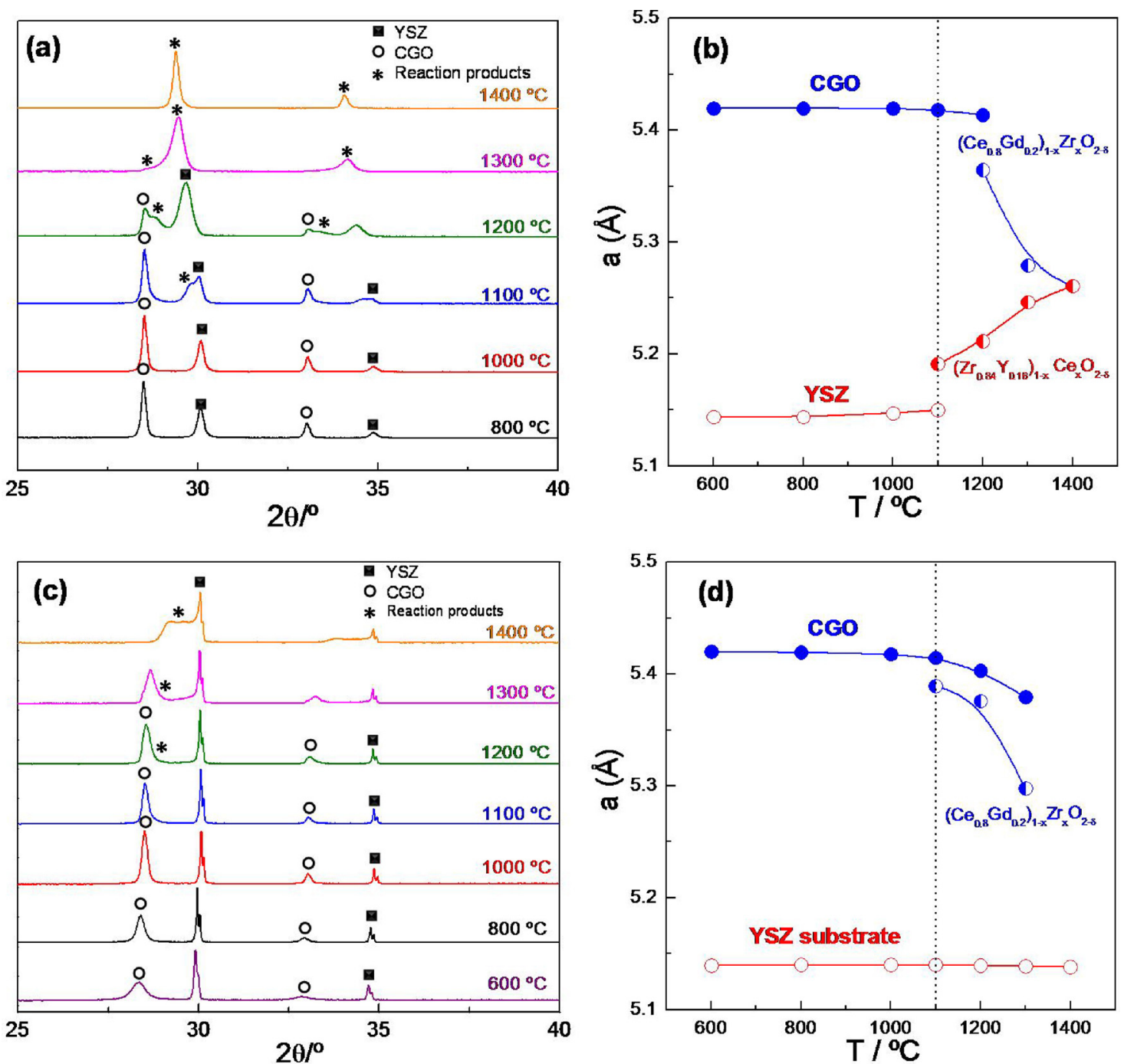

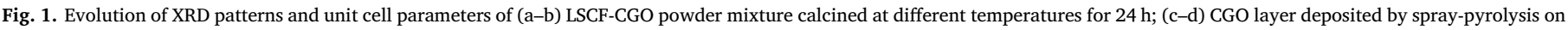
YSZ after calcining at different temperatures for $24 \mathrm{~h}$. Arrows indicate the asymmetry of the peaks due to bulk reaction between CGO and YSZ layers.

fluorite-type phases are necessary to fit the data adequately, i.e. the YSZ substrate, the CGO protective layer and a reaction product. Above $1300{ }^{\circ} \mathrm{C}$, the peak overlapping makes difficult the Rietveld analysis and the cell parameters are not determined. The unit cell variation clearly indicates that the bulk reaction is significant above $1100{ }^{\circ} \mathrm{C}$ (Fig. $1 \mathrm{~d}$ ).

The reactivity between YSZ and LSCF was also confirmed after annealing a powder mixture of both materials at $800{ }^{\circ} \mathrm{C}$ for $24 \mathrm{~h}$. The corresponding XRD pattern showed an additional peak at $2 \theta=31^{\circ}$, which is assigned to $\mathrm{SrZrO}_{3}$ (ICSD \#650) (Fig. S1, supplementary information).

Fig. 2 shows the XRD patterns of the LSCF/CGO/YSZ cells prepared by conventional and spray-pyrolysis deposition methods at $1100{ }^{\circ} \mathrm{C}$ and $800^{\circ} \mathrm{C}$, respectively. The patterns show similar features and three different phases are identified. The most intense peaks correspond to the top LSCF layer and the less intense ones are assigned to the bottom CGO interlayer and YSZ substrate. Notice that the XRD peaks of the sample prepared by spray-pyrolysis are broad due to the lower preparation temperature, and consequently, the lower crystallinity and smaller particle size of the materials. It is also important to highlight that bulk reactivity with the presence of secondary phases are not detected. Moreover, the unit cell volume of CGO, YSZ and LSCF phases are similar to the pristine materials, indicating that the same compounds are obtained, independently on the deposition method used.

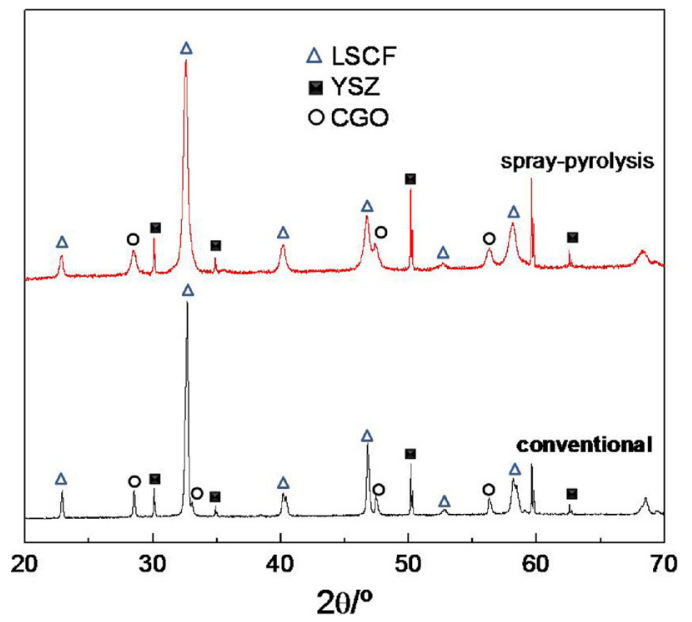

Fig. 2. XRD patterns of the cells prepared by conventional deposition methods at $1000^{\circ} \mathrm{C}$ and spray-pyrolysis at $800{ }^{\circ} \mathrm{C}$. The different compounds are identified with symbols.

\subsection{Microstructural characterization}

Fig. 3 compares the microstructure of the CGO layers without and with $2 \mathrm{~mol} \%$ of cobalt as sintering aid. The layers without Co are highly 

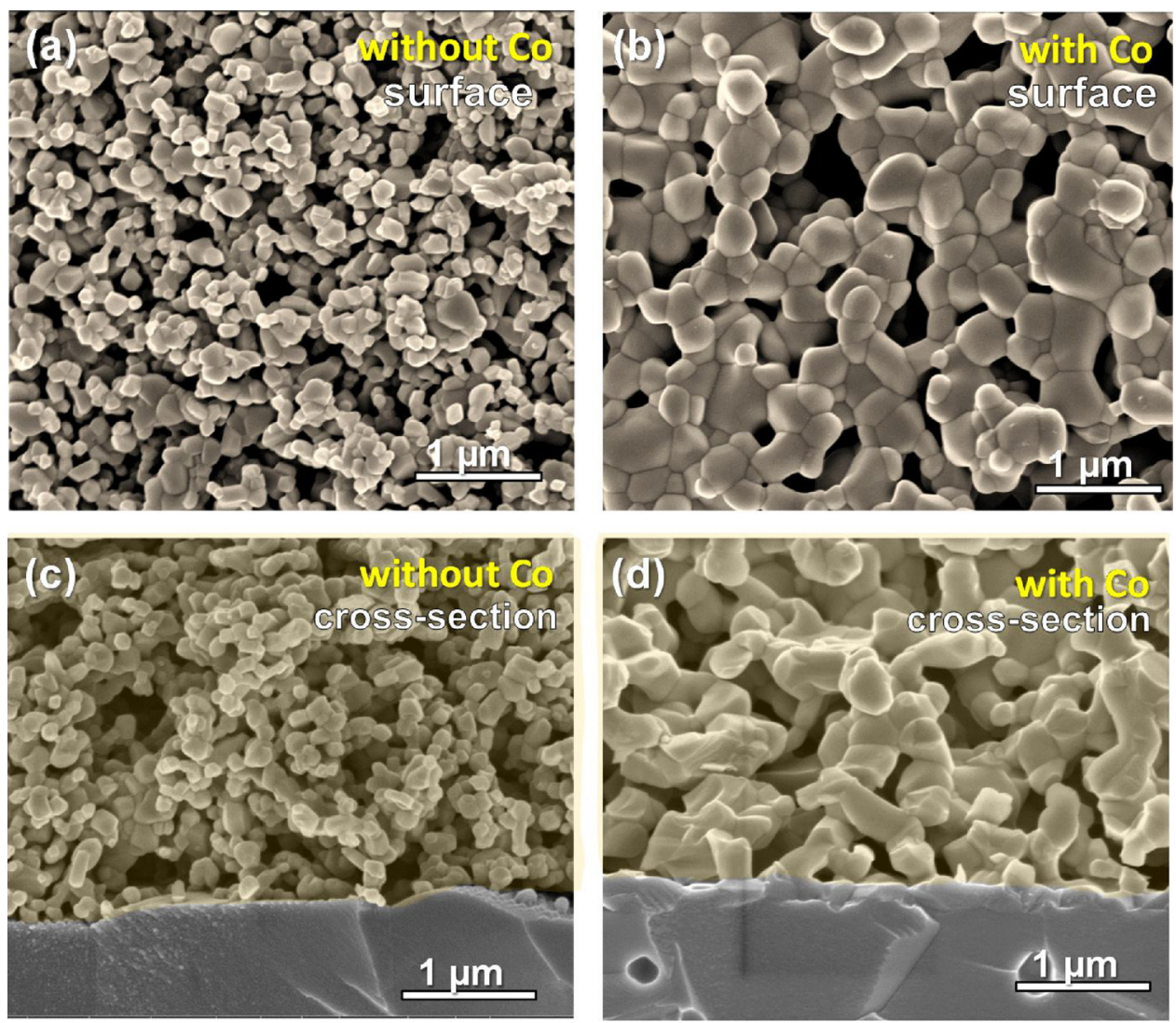

Fig. 3. SEM image of the surface and cross-section of the CGO layers deposited by airbrushing (a-b) without sintering aids at $1100{ }^{\circ} \mathrm{C}$ and (c-d) with Co-addition at $1000{ }^{\circ} \mathrm{C}$.

porous, above $45 \%$, and exhibit poor adhesion to the electrolyte, which makes them unsuitable for practical application in SOFCs (Fig. 2a and b). As a consequence, these layers are not further characterized in the present study.

In contrast, the layers with Co addition present lower porosity, $\sim 30 \%$, and larger grain size of $\sim 500 \mathrm{~nm}$ due to the sintering effects of cobalt, which improves the densification and the grain growth. Notice that sintering temperatures above $1100{ }^{\circ} \mathrm{C}$ lead to a decrease of the relative density, which is explained by Co evaporation and the consequent loss of densification [20,21]. It is also important to comment that full dense CGO pellets with Co-addition are obtained at $1000{ }^{\circ} \mathrm{C}$; however, the shrinkage of the analogous layers is mechanically constrained by the YSZ substrate, hindering their densification.

As commented in the experimental section, the LSCF cathode was symmetrically deposited by screen-printing and sintering at $1000{ }^{\circ} \mathrm{C}$ for $1 \mathrm{~h}$ on the CGO layers. Afterwards, the cells were annealed at $800^{\circ} \mathrm{C}$ for $250 \mathrm{~h}$ and then analyzed by combined SEM and EDX (Fig. 4). The crosssectional images reveal that the CGO layer has a thickness of approximately $4 \mu \mathrm{m}$ and is well adhered to the electrolyte without delamination or cracks. The microstructure of LSCF cathode remains practically unchanged after the annealing treatment; thus significant grain growth and loss of porosity are not observed. The most remarkable difference with respect to the as-prepared sample is the presence of a reaction zone at the CGO/YSZ interface. The EDX mapping reveals that this region is Sr-rich due to the Sr-diffusion through the CGO barrier and the consequent formation of $\mathrm{SrZrO}_{3}$. Hence, the level of densification of these CGO layers (70\% of relative density) is not enough to prevent the $\mathrm{Sr}$ diffusion from the cathode to the electrolyte. It is also important to mention that the EDX mapping of Ce and $\mathrm{Zr}$ reveal certain interdiffusion at the interface, which mainly occurs during the fabrication process at $1000^{\circ} \mathrm{C}$, because this behavior is not observed in samples prepared by spray-pyrolysis at lower sintering temperatures as discussed below.
The microstructure of the cell prepared by spray-pyrolysis before and after the annealing treatment at $800^{\circ} \mathrm{C}$ for $250 \mathrm{~h}$ is shown in Fig. 5 . The as-prepared cell shows a CGO interlayer of $0.5-1 \mu \mathrm{m}$ thickness (Fig. 5a). This layer is dense and is formed by fine particles of approximately $30 \mathrm{~nm}$ of diameter. The EDX analysis does not show any sign of reactivity, either cation interdiffusion at the interface between the different layers. Regarding the LSCF cathode, this exhibits high porosity and is comprised by nanometric particles of $100 \mathrm{~nm}$ of diameter. However, after the annealing treatment at $800^{\circ} \mathrm{C}$, the microstructure reveals noticeable changes (Fig. $5 \mathrm{~b}$ ). In particular, the grain size of CGO and LSCF grows to $150 \mathrm{~nm}$ and $250 \mathrm{~nm}$, respectively, as a consequence of the coarsening effects after long term annealing at high temperatures. Moreover, despite the fact that the CGO layer is dense, Sr-segregation is observed in certain regions at the CGO/YSZ interface, possibly due to $\mathrm{Sr}$ diffusion through the grain boundaries of CGO barrier as other authors have reported [14,15]. It is also important to comment that the reaction zone in dense CGO barrier is significantly smaller compared to the porous CGO layer. These results are consistent with previous studies, where the $\mathrm{Sr}$ diffusion mechanism is faster though the porous than the grain boundary of CGO interlayer [14]. In addition, the EDX mapping reveals a negligible interdiffusion between $\mathrm{Zr}$ and $\mathrm{Ce}$, contrary to the CGO barriers prepared by airbrushing at higher firing temperatures.

\subsection{Polarization resistance over time}

The polarization resistance of the symmetrical cells was determined by impedance spectroscopy in the temperature range of $300-800^{\circ} \mathrm{C}$. Fig. 6 compares the overall polarization resistance of the different samples as a function of the temperature. It is important to comment that these measurements correspond to the as-prepared samples, without any previous annealing treatment. The cell without CGO interlayer exhibits a polarization resistance $\left(R_{p}\right)$ of $0.10 \Omega \mathrm{cm}^{2}$ at $800^{\circ} \mathrm{C}$, 

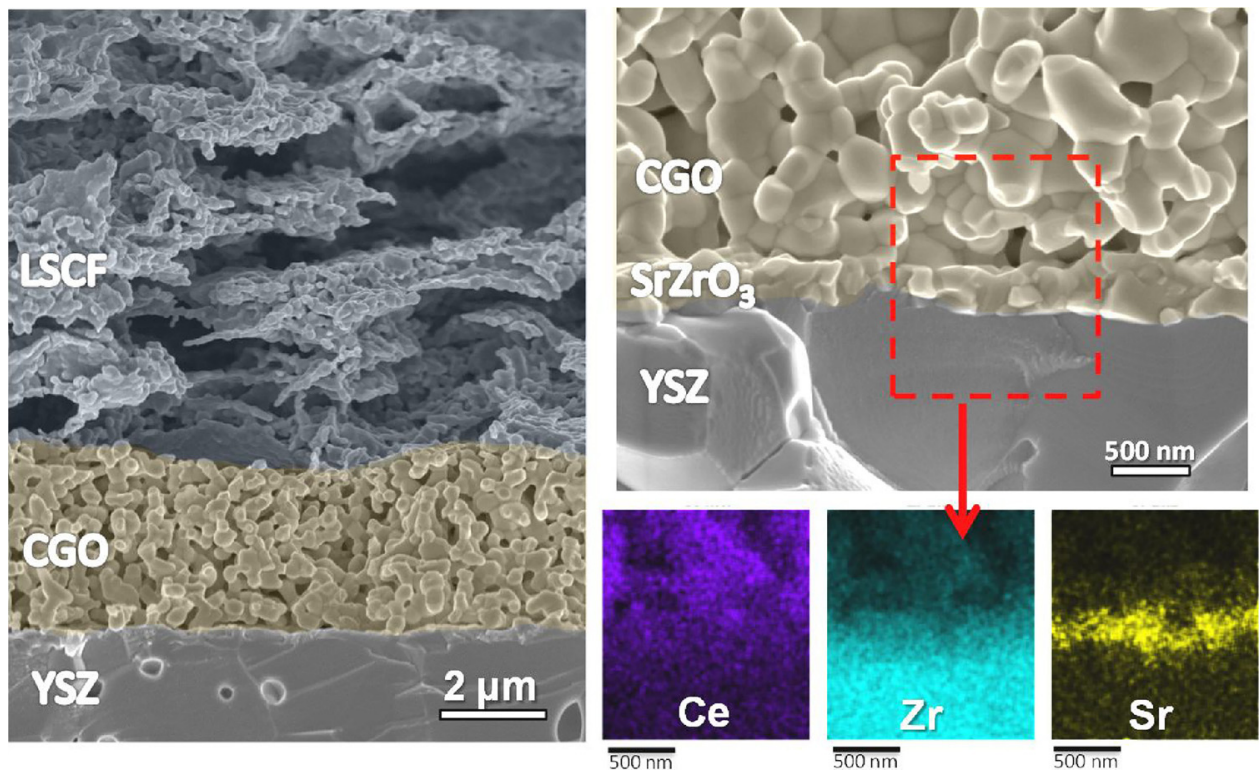

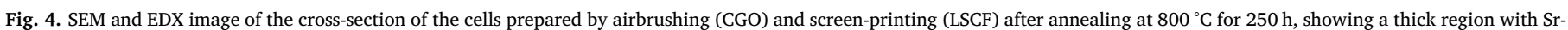
enrichment at the CGO/YSZ interface.
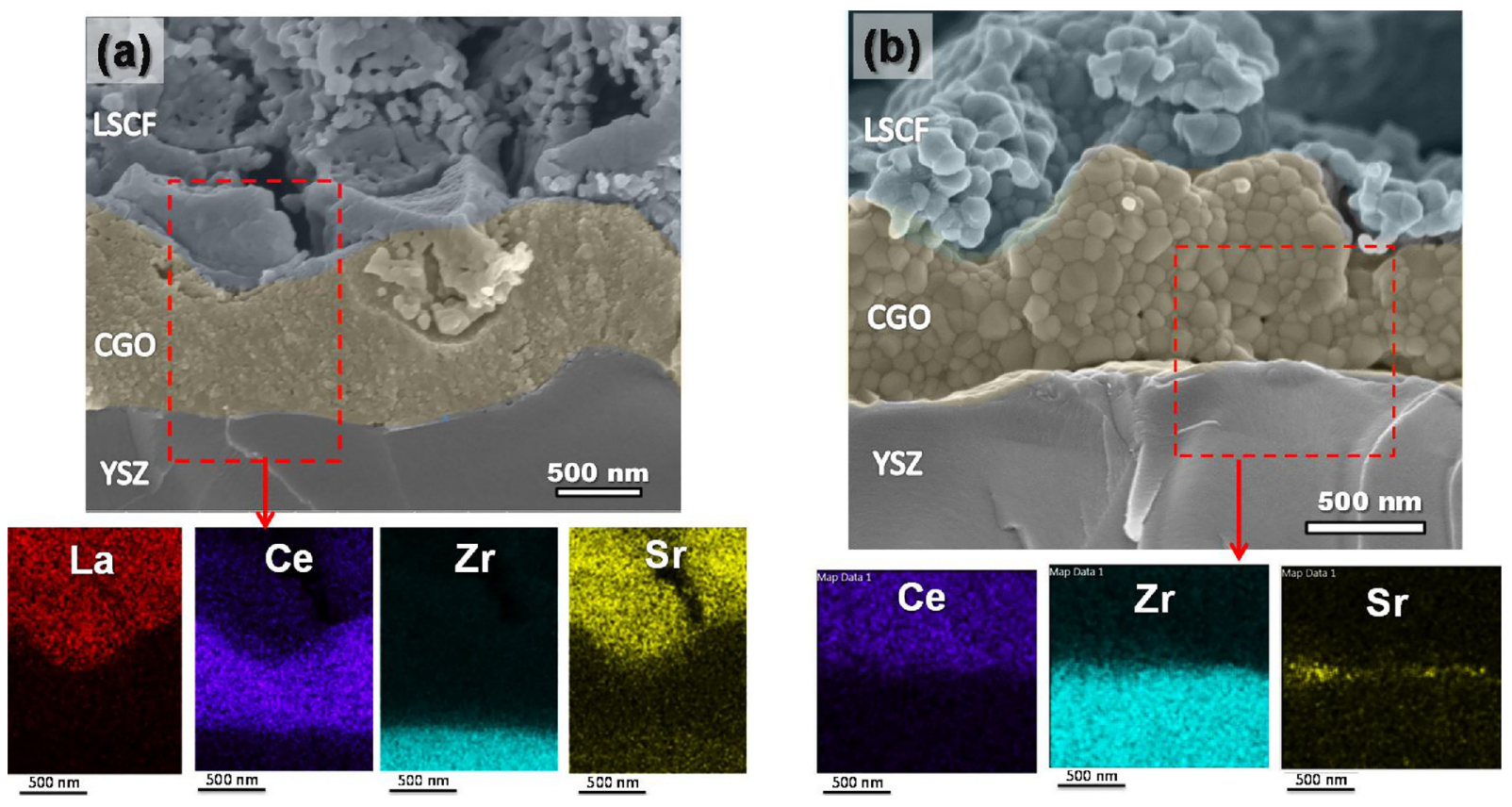

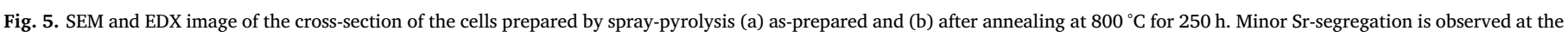
CGO/YSZ interface after the annealing treatment.

somewhat higher than that of LSCF deposited on CGO electrolyte, 0.055 $\Omega \mathrm{cm}^{2}$ [46]. This result indicates that the possible reaction between LSCF and YSZ has not significant effects on the electrochemical properties during the fabrication process at $1000{ }^{\circ} \mathrm{C}$ for only $1 \mathrm{~h}$. The conventional cell with CGO interlayer shows somewhat lower $R_{p}$, about $0.051 \Omega \mathrm{cm}^{2}$ at $800{ }^{\circ} \mathrm{C}$, which is possibly attributed to the oxygen incorporation improvement at the cathode/electrolyte interface as a consequence of the higher ionic conductivity of CGO compared to YSZ. This value of polarization resistance is almost identical to that obtained for LSCF in contact with the CGO electrolyte [46]. The cells with spraypyrolysis layers exhibit the lowest $R_{p}$ values, about $0.014 \Omega \mathrm{cm}^{2}$ at $800^{\circ} \mathrm{C}$, which is clearly related to the fine particle size of these electrodes and the extended triple-phase-boundary length for the oxygen reduction reactions [32-34]. Regarding the activation energies, these vary between 1.71 and $1.43 \mathrm{eV}$ with the highest value for the conventional cell without CGO interlayer and the lowest one for the cell with spray-pyrolysis electrodes. This last value is similar to that reported for LSCF in contact with CGO electrolyte, $1.47 \mathrm{eV}$ [46].

The variation of the overall polarization resistance over time at isothermal annealing temperatures of 800 and $650{ }^{\circ} \mathrm{C}$ are shown in Fig. 7. In the high temperature range (Fig. 7a), the sample without CGO interlayer suffers a fast degradation of both the ohmic $\left(\mathrm{R}_{\mathrm{ohm}}\right)$ and polarization $\left(R_{p}\right)$ resistances, nevertheless, the ohmic resistance is less affected than the polarization resistance, suggesting that the degradation is mainly associated with the alteration of the electrolyte/cathode interface. For instance, $R_{p}$ increases from 0.1 to $3 \Omega \mathrm{cm}^{2}$, while $R_{\text {ohm }}$ increases from 13.1 to $13.6 \Omega \mathrm{cm}$ during a period of time of $125 \mathrm{~h}$ (Fig. S2). 


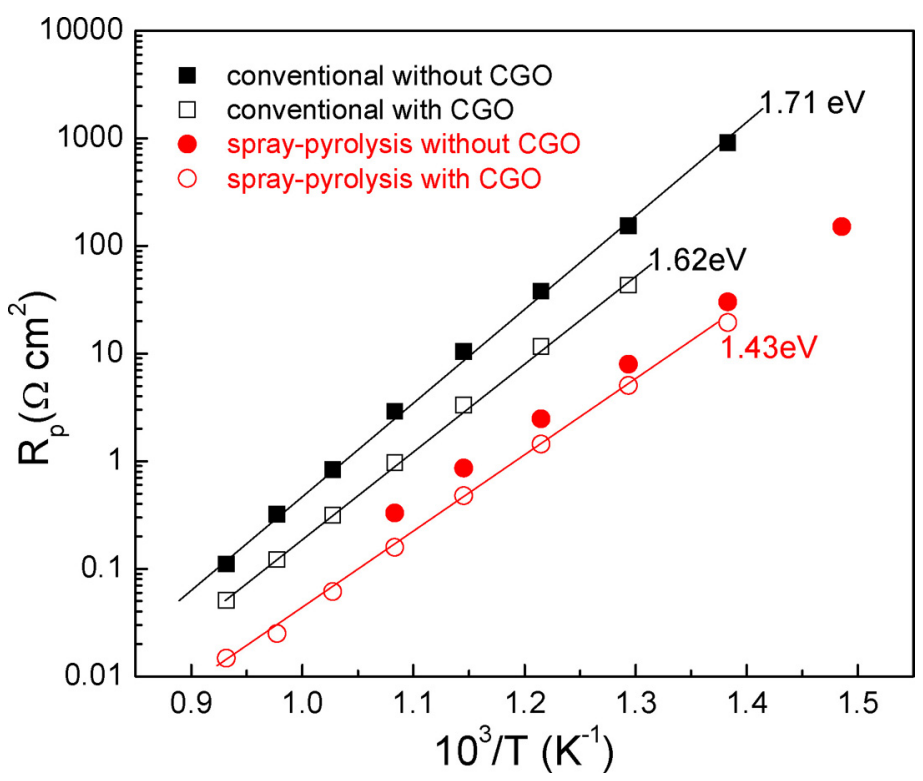

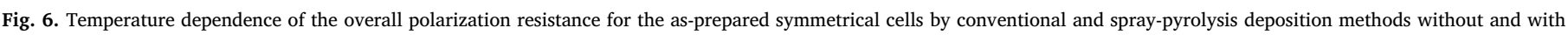
CGO interlayer.

A more interesting finding, the cathode prepared by spray-pyrolysis directly onto YSZ electrolyte exhibits somewhat lower degradation rate, compared to the samples deposited by conventional methods, i.e. $R_{p}$ increases from 0.04 to $0.21 \Omega \mathrm{cm}^{2}$. This behavior could be related to several factors, such as the lower fabrication temperature and lower crystallinity of the electrodes obtained by spray-pyrolysis, which limit the $\mathrm{Sr}$ diffusion at the electrolyte/electrode interface [47]. These issues are further discussed below.

The introduction of the CGO interlayer by airbrushing improves notably the performance and durability of the cell; however, degradation is still observed at high operating temperatures, i.e. $\mathrm{R}_{\mathrm{p}}$ increases from 0.048 to $0.09 \Omega \mathrm{cm}^{2}$. In the case of the cell prepared by spraypyrolysis, the polarization resistance increases significantly for the first 50 hours, due to microstructural changes, i.e. grain growth and densification, since this cell was prepared at a reduced temperature of only $800^{\circ} \mathrm{C}$. Afterwards, $\mathrm{R}_{\mathrm{p}}$ increases more slowly from 0.016 to $0.039 \Omega \mathrm{cm}^{2}$.

It is also important to comment that the performance of LSCF decays over time at high operating temperatures due to phase segregations on the electrode surface, such as Sr-enrichment, which blocks the active sites for oxygen reduction reaction [48-50]. Thus, the performance degradation of these cells at high operating temperatures includes two different contributions, interfacial reactivity at the CGO/YSZ interface and surface phase segregation. This issue is further discussed below by studying separately the different processes to the electrode polarization.

Hence, it is evident that the potential application of LSCF should be restricted at the low temperature range. For this reason, the stability of the samples was also evaluated at $650{ }^{\circ} \mathrm{C}$ (Fig. $7 \mathrm{~b}$ ). Hereafter, only the samples prepared by spray-pyrolysis with improved performance are further analyzed. The polarization resistance of LSCF in contact with YSZ increases from 0.32 to $0.61 \Omega \mathrm{cm}^{2}$, indicating that the reaction between YSZ and LSCF is still significant at a reduced temperatures of $650^{\circ} \mathrm{C}$. In contrast, the sample with CGO interlayer exhibits a stable polarization resistance over time of $0.15 \Omega \mathrm{cm}^{2}$. Hence, the Sr-diffusion though the dense CGO barrier and the loss of performance associated with surface segregation are negligible at $650{ }^{\circ} \mathrm{C}$ for samples prepared
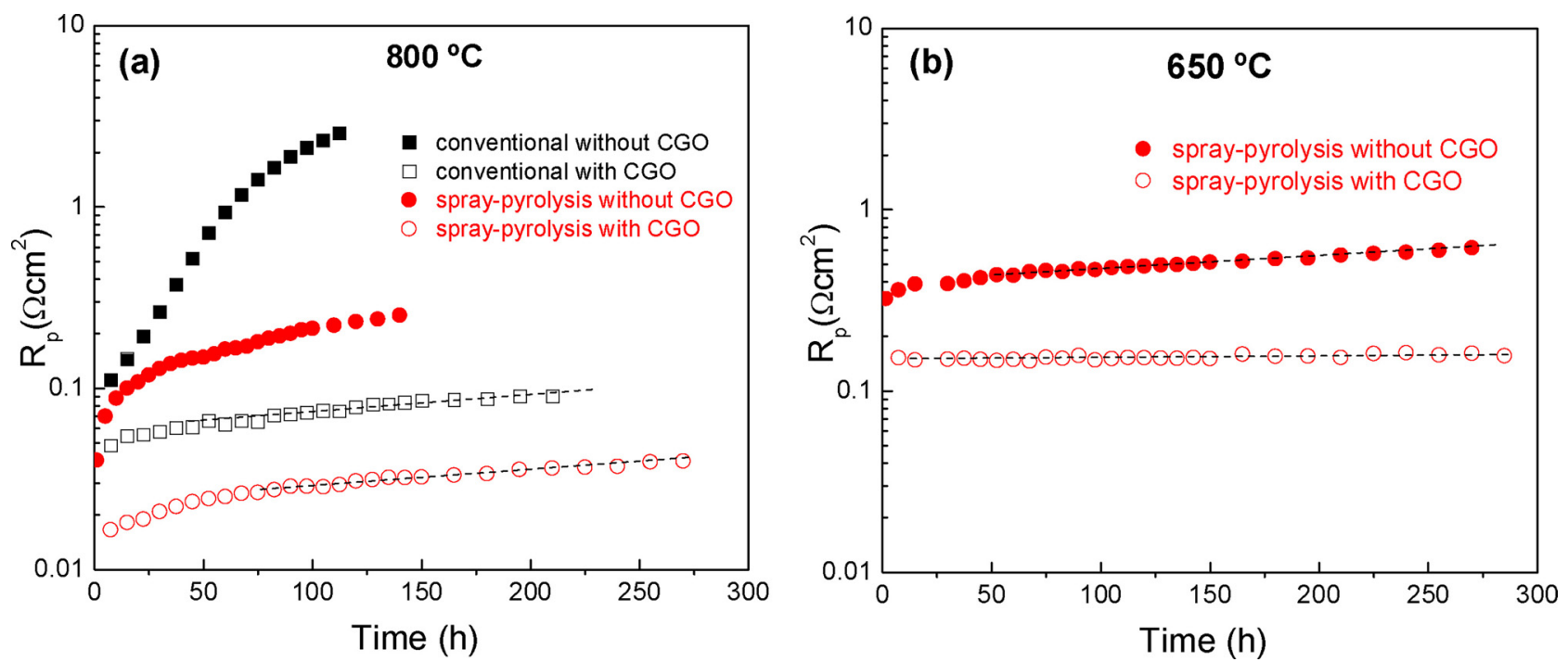

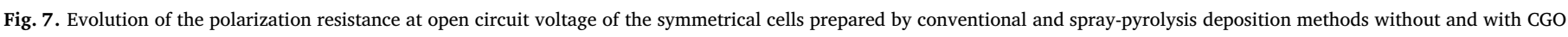
interlayer at (a) $800{ }^{\circ} \mathrm{C}$ and (b) $650{ }^{\circ} \mathrm{C}$. 

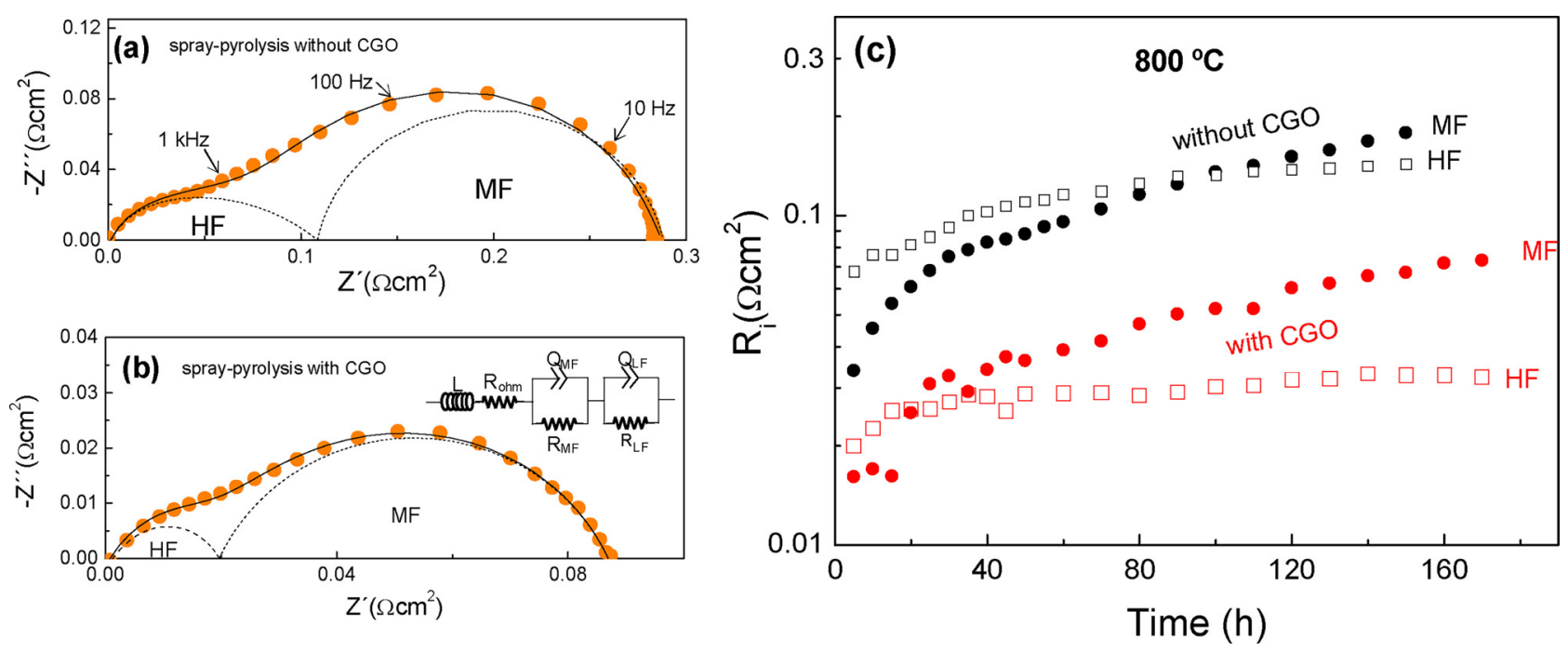

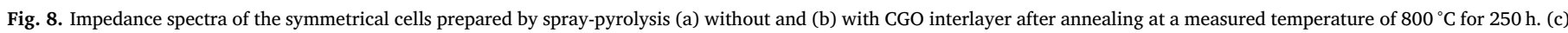
Variation of the MF and LF resistance contributions to the polarization resistance.

by spray-pyrolysis. In addition, these samples exhibit improved performance and durability when compared to LSCF cathodes deposited on CGO electrolyte by conventional screen-printing technique in a previous work, i.e. $R_{p}$ increased from 2.8 to $7 \Omega \mathrm{cm}^{2}$ at $650{ }^{\circ} \mathrm{C}$ for $200 \mathrm{~h}$ [46].

In order to obtain further insights on the different processes of the electrode polarization, the impedance spectra of the samples prepared by spray-pyrolysis are analyzed by equivalent circuit models (Fig. 8a and b). Two different processes are distinguished at medium (MF) and low frequency (LF), which are fitting by considering two (RQ) elements, where $\mathrm{R}$ is a resistance in parallel with a pseudo-capacitance $\mathrm{Q}$. A serial resistance $\left(R_{\text {ohm }}\right)$ and an inductance $(L)$ are also included to take into consideration the ohmic losses of the samples and parasitic inductance effects introduced by the setup, respectively (inset Fig. 8b).

The MF contribution appears at a relaxation frequency of approximately $15 \mathrm{kHz}$ and possesses a capacitance of about $0.1 \mathrm{mFcm}^{-2}$, consistent with a charge transfer process at the electrode/electrolyte interface. The LF contribution at $\sim 100 \mathrm{~Hz}$ has a higher capacitance, $\sim 10 \mathrm{mFcm}^{-2}$, and is assigned to the dissociation adsorption of oxygen molecules on the electrode surface [51-53].

The evolution of the resistance contributions, $\mathrm{R}_{\mathrm{MF}}$ and $\mathrm{R}_{\mathrm{HF}}$, at an annealing temperature of $800{ }^{\circ} \mathrm{C}$ is displayed in Fig. 8c. The HF contribution, related to charge transfer, increases more slowly for the sample with CGO barrier, indicating a lower degradation of the electrode/electrolyte interface. The MF contribution suffers a stronger increase during the first $40 \mathrm{~h}$ for both samples without and with CGO barrier, which is related to the microstructural changes likely coarsening and grain growth as previously commented. Such as grain growth, reduces the number of reaction sites for oxygen dissociation on the surface, and consequently the associated resistance increases. Afterwards, $\mathrm{R}_{\mathrm{MF}}$ increases almost linearly over time. Notice also that the degradation for prolonged times is similar for samples without and with CGO interlayer. Hence, this behavior may be attributed to superficial Sr-enrichment at the electrode surface, which blocks the active sites for oxygen reduction reactions [50].

More importantly, the samples prepared by spray-pyrolysis exhibit a lower degradation of the MF contribution compared to those prepared by conventional methods [46,54]. This behavior could be explained by the different level of surface segregation, depending on the synthetic method used [47]. In general, the level of cation segregation is determined by the nature of the cathode, such as composition, cation deficiency and crystallinity; and the environmental conditions, such as temperature, atmosphere, and electrical polarization. For instance, cation segregation is favored at elevated temperatures and prolonged annealing time. A-site surface segregation in $\mathrm{ABO}_{3}$ perovskites is generally suppressed by cathodic polarization. Finally, several studies have reported that materials with a higher crystallinity present a more orderly arrangement with less free space in the lattice, driving the dopants with larger radii, such as $\mathrm{Sr}^{2+}$, to the surface $[47,55,56]$. Hence, the lower crystallinity of the samples prepared by spray-pyrolysis with respect to those obtained by conventional methods could explain the different degradation rate of the $\mathrm{R}_{\mathrm{MF}}$ and $\mathrm{R}_{\mathrm{LF}}$ contributions to the polarization.

In summary, at very high operating temperatures, both reactivity at the electrode/electrolyte interface and surface segregation are serious drawbacks for the performance and durability of LSCF cathodes. Hence, the application of LSCF cathodes needs to be restricted at the low temperature range.

\section{Conclusions}

CGO barrier layers were prepared by conventional airbrushing and spray-pyrolysis deposition methods to prevent the interfacial reactivity between the YSZ electrolyte and the LSCF cathode.

The chemical compatibility studies between YSZ and CGO showed a significant reactivity between both materials above $1100{ }^{\circ} \mathrm{C}$ and the subsequent worsening of the electrical properties; therefore sintering procedures at lower temperatures and shorter times are necessary.

An airbrushing technique was employed to obtain uniform and thin CGO layer of $4 \mu \mathrm{m}$ of thickness. The use of Co as sintering aids allowed reducing the sintering temperature to $1000^{\circ} \mathrm{C}$, giving rise to protective layers with adequate adhesion to the YSZ electrolyte and relative density above $70 \%$. However, the level of densification of these layers was not sufficient to avoid Sr-diffusion from LSCF cathode to the CGO/ YSZ interface.

Dense CGO interlayers and porous LSCF cathodes were subsequently deposited by spray-pyrolysis onto the YSZ electrolyte. Minor Sr-segregation was observed at the CGO/YSZ interface after annealing at $800^{\circ} \mathrm{C}$ for $250 \mathrm{~h}$, which was accompanied by an increase of the electrode polarization resistance.

The phase segregation on the LSCF surface was another important performance degradation mechanism at high annealing temperatures, which was identified by studying separately the different contributions of the impedance spectra.

Polarization resistance studies after long term annealing confirmed that the LSCF cathode deposited by spray-pyrolysis exhibit better 
stability than those prepared by conventional deposition methods. This was mainly attributed to its lower particle size and crystallinity, which partially suppress the interfacial reactivity and the surface phase segregation.

\section{Acknowledgements}

This work has been supported by EC2014-53906-R and MAT201677648-R research grants (Spain). L. dos Santos-Gómez thanks to the Spanish Ministry of Education, Culture and Sports for her FPU grant (FPU13/03030). J.M. Porras-Vázquez thanks the University of Malaga for the funding.

\section{Appendix A. Supplementary data}

Supplementary material related to this article can be found, in the online version, at doi:https://doi.org/10.1016/j.jeurceramsoc.2018.03. 024.

\section{References}

[1] D.J.L. Brett, A. Atkinson, N.P. Brandon, S.J. Skinner, Intermediate temperature solid oxide fuel cells, Chem. Soc. Rev. 37 (2008) 1568-1578.

[2] E.D. Wachsman, K.T. Lee, Lowering the temperature of solid oxide fuel cells, Science 334 (2011) 935-939.

[3] Z. Gao, L.V. Mogni, E.C. Miller, J.G. Railsback, S.A. Barnett, A perspective on lowtemperature solid oxide fuel cells, Energy Environ. Sci. 9 (2016) 1602-1644.

[4] A.J. Jacobson, Materials for solid oxide fuel cells, Chem. Mater. 22 (2010) 660-674.

[5] A. Jun, J. Kim, J. Shin, G. Kim, Perovskite as a cathode material: a review of its role in solid-oxide fuel cell technology, ChemElectroChem 3 (2016) 511-530.

[6] L. Qiu, T. Ichikawa, A. Hirano, N. Imanishi, Y. Takeda, $\mathrm{Ln}_{1-\mathrm{x}} \mathrm{Sr}_{\mathrm{x}} \mathrm{Co}_{1-\mathrm{y}} \mathrm{Fe}_{\mathrm{y}} \mathrm{O}_{3-\delta}$ $(\mathrm{Ln}=\mathrm{Pr}, \mathrm{Nd}, \mathrm{Gd} ; \mathrm{x}=0.2,0.3)$ for the electrodes of solid oxide fuel cells, Solid State Ionics 158 (2003) 55-65.

[7] W.G. Wang, M. Mogensen, High-performance lanthanum-ferrite-based cathode for SOFC, Solid State Ionics 176 (2005) 457-462.

[8] G.C. Kostogloudis, G. Tsiniarakis, C. Ftikos, Chemical reactivity of perovskite oxide SOFC cathodes and yttria stabilized zirconia, Solid State Ionics 135 (2000) $529-535$.

[9] S.P. Simner, J.P. Shelton, M.D. Anderson, J.W. Stevenson, Interaction between La ( $\mathrm{Sr}) \mathrm{FeO}_{3} \mathrm{SOFC}$ cathode and YSZ electrolyte, Solid State Ionics 161 (2003) 11-18.

[10] A. Tsoga, A. Gupta, A. Naoumidis, P. Nikolopoulos, Gadolinia-doped ceria and yt tria stabilized zirconia interfaces: regarding their application for SOFC technology, Acta Mater. 48 (2000) 4709-4714.

[11] R. Knibbe, J. Hjelm, M. Menon, N. Pryds, M. Søgaard, H.J. Wang, K. Neufeld, Cathode-electrolyte interfaces with CGO barrier layers in SOFC, J. Am. Ceram. Soc. 93 (2010) 2877-2883.

[12] J. Peña-Martínez, D. Marrero-López, C. Sánchez-Bautista, A.J. dos Santos-García, J.C. Ruíz-Morales, J. Canales-Vázquez, P. Núñez, Effect of a CGO buffer layer on the performance of $\left(\mathrm{La0} .6 \mathrm{Sr}_{0.4}\right)_{0.995} \mathrm{Co}_{0.2} \mathrm{Fe}_{0.8} \mathrm{O}_{3-\delta}$ cathode in YSZ-based SOFC, Bol. Soc. Esp. Ceram. 49 (2010) 15-22.

[13] M. Morales, V. Miguel-Pérez, A. Tarancón, A. Slodczyk, M. Torrell, B. Ballesteros, J.P. Ouweltjes, J.M. Bassat, D. Montinaro, A. Morata, Multi-scale analysis of the diffusion barrier layer of gadolinia-doped ceria in a solid oxide fuel cell operated in a stack for 3000 h, J. Power Sources 344 (2017) 141-151.

[14] M. Izuki, M.E. Brito, K. Yamaji, H. Kishimoto, D.H. Cho, T. Shimonosono, T. Horita, H. Yokokawa, Interfacial stability and cation diffusion across the LSCF/GDC interface, J. Power Sources 196 (2011) 7232-7236.

[15] F. Wang, M. Nishi, M.E. Brito, H. Kishimoto, K. Yamaji, H. Yokokawa, T. Horita, Sr and Zr diffusion in LSCF/10GDC/8YSZ triplets for solid oxide fuel cells (SOFCs), J. Power Sources 258 (2014) 281-289.

[16] F. Wang, M.E. Brito, K. Yamaji, D.H. Cho, M. Nishi, H. Kishimoto, T. Horita, H. Yokokawa, Effect of polarization on Sr and Zr diffusion behavior in LSCF/GDC/ YSZ system, Solid State Ionics 262 (2014) 454-459.

[17] L. Adijanto, R. Küngas, F. Bidrawn, R.J. Gorte, J.M. Vohs, Stability and performance of infiltrated $\mathrm{La0} .8 \mathrm{Sr}_{0.2} \mathrm{Co}_{\mathrm{x}} \mathrm{Fe}_{1-\mathrm{x}} \mathrm{O}_{3}$ electrodes with and without $\mathrm{Sm}_{0.2} \mathrm{Ce} 0.8 \mathrm{O}_{1.9}$ interlayers, J. Power Sources 196 (2011) 5797-5802.

[18] A. Tsoga, A. Naoumidis, D. Stöver, Total electrical conductivity and defect structure of $\mathrm{ZrO}_{2}-\mathrm{CeO}_{2}-\mathrm{Y}_{2} \mathrm{O}_{3}-\mathrm{Gd}_{2} \mathrm{O}_{3}$ solid solutions, Solid State Ionics 135 (2000) 403-409.

[19] C. Kleinlogel, L.J. Gauckler, Sintering and properties of nanosized ceria solid solutions, Solid State Ionics 135 (2000) 567-573.

[20] T. Zhang, P. Hing, H. Huang, J. Kilner, Sintering and grain growth of CoO-doped $\mathrm{CeO}_{2}$ ceramics, J. Eur. Ceram. Soc. 22 (2002) 27-34.

[21] D. Pérez-Coll, D. Marrero-López, P. Núñez, S. Piñol, J.R. Frade, Grain boundary conductivity of $\mathrm{Ce} 0.8 \mathrm{Ln}_{0.2} \mathrm{O}_{2-\delta}$ ceramics ( $\mathrm{Ln}=\mathrm{Y}, \mathrm{La}, \mathrm{Gd}, \mathrm{Sm}$ ) with and without Codoping, Electrochim. Acta 51 (2006) 6463-6469.

[22] C. Nicollet, J. Waxin, T. Dupeyron, A. Flura, J.M. Heintz, J.P. Ouweltjes, P. Piccardo, A. Rougier, J.C. Grenier, J.M. Bassat, Gadolinium doped ceria interlayers for solid oxide fuel cells cathodes: enhanced reactivity with sintering aids (Li, $\mathrm{Cu}, \mathrm{Zn}$ ), and improved densification by infiltration, J. Power Sources 372 (2017)
$157-165$.

[23] D. Ramasamy, N. Nasani, A.D. Brandão, D. Pérez Coll, D.P. Fagg, Enhancing electrochemical performance by control of transport properties in buffer layers-solid oxide fuel/electrolyser cells, Phys. Chem. Chem. Phys. 17 (2015) 11527-11539.

[24] S. Sønderby, T. Klemensø, B.H. Christensen, K.P. Almtoft, J. Lu, L.P. Nielsen, P. Eklund, Magnetron sputtered gadolinia-doped ceria diffusion barriers for metalsupported solid oxide fuel cells, J. Power Sources 267 (2014) 452-458.

[25] S. Sønderby, P.L. Popa, J. Lu, B.H. Christensen, K.P. Almtoft, L.P. Nielsen, P. Eklund, Strontium diffusion in magnetron sputtered gadolinia-doped ceria thin film barrier coatings for solid oxide fuel cells, Adv. Energy Mater. 3 (2013) 923-929.

[26] S. Uhlenbruck, N. Jordan, D. Sebold, H. Buchkremer, V. Haanappel, D. Stöver, Thin film coating technologies of $(\mathrm{Ce}, \mathrm{Gd}) \mathrm{O}_{2-\delta}$ interlayers for application in ceramic hightemperature fuel cells, Thin Solid Films 515 (2007) 4053-4060.

[27] G. Constantin, C. Rossignol, P. Briois, A. Billard, L. Dessemond, E. Djurado, Efficiency of a dense thin CGO buffer layer for solid oxide fuel cell operating at intermediate temperature, Solid State Ionics 249-250 (2013) 98-104.

[28] D. Chen, G. Yang, Z. Shao, F. Ciucci, Nanoscaled Sm-doped $\mathrm{CeO}_{2}$ buffer layers for intermediate- temperature solid oxide fuel cells, Electrochem. Commun. 35 (2013) 131-134.

[29] P. Plonczak, M. Joost, J. Hjelm, M. Søgaard, M. Lundberg, P.V. Hendriksen, A high performance ceria based interdiffusion barrier layer prepared by spin-coating, J. Power Sources 196 (2011) 1156-1162.

[30] D. Perednis, L.J. Gauckler, Solid oxide fuel cells with electrolytes prepared via spray pyrolysis, Solid State Ionics 166 (2004) 229-239.

[31] A. Evans, A. Bieberle-Hütter, J.L.M. Rupp, L.J. Gauckler, Review on microfabricated micro-solid oxide fuel cell membranes, J. Power Sources 194 (2009) 119-129.

[32] L. dos Santos-Gómez, E.R. Losilla, F. Martín, J.R. Ramos-Barrado, D. Marrero-López, Novel microstructural strategies to enhance the electrochemical performance of $\mathrm{La}_{0.8} \mathrm{Sr}_{0.2} \mathrm{MnO}_{3-\delta}$ cathodes, ACS Appl. Mater. Inter. 7 (2015) 7197-7205.

[33] D. Marrero-López, L. dos Santos-Gómez, J. Canales-Vázquez, F. Martín, J.R. RamosBarrado, Stability and performance of nanostructured $\mathrm{La}_{0.8} \mathrm{Sr}_{0.2} \mathrm{MnO}_{3}$ cathodes deposited by spray-pyrolysis, Electrochim. Acta 134 (2014) 159-166.

[34] A. Princivalle, D. Perednis, R. Neagu, E. Djurado, Porosity control of LSM/YSZ cathode coating deposited by electrospraying, Chem. Mater. 17 (2005) 1220-1227.

[35] D. Szymczewska, J. Karczewski, A. Chrzan, P. Jasinski, CGO as a barrier layer between LSCF electrodes and YSZ electrolyte fabricated by spray pyrolysis for solid oxide fuel cells, Solid State Ionics 302 (2017) 113-117.

[36] B. Scherrer, J. Martynczuk, H. Galinski, J.G. Grolig, S. Binder, A. Bieberle-Hütter, J.L.M. Rupp, M. Prestat, L.J. Gauckler, Microstructures of YSZ and CGO thin film deposited by spray pyrolysis: influence of processing parameters on the porosity, Adv.Funct. Mater. 22 (2012) 3509-3518.

[37] D. Szymczewska, A. Chrzan, J. Karczewski, S. Molin, P. Jasinski, Spray pyrolysis of doped-ceria barrier layers for solid oxide fuel cells, Surf. Coat. Technol. 313 (2017) $168-176$.

[38] D. Marrero-López, M.C. Martín-Sedeño, J. Peña-Martínez, J.C. Ruíz-Morales, P. Núñez, M.A.G. Aranda, J.R. Ramos-Barrado, Evaluation of apatite silicates as solid oxide fuel cell electrolytes, J. Power Sources 195 (2010) 2496-2506.

[39] A.J. Fernández-Ropero, J.M. Porras-Vázquez, A. Cabeza, P.R. Slater, D. MarreroLópez, E.R. Losilla, High valence transition metal doped strontium ferrites for electrode materials in symmetrical SOFCs, J. Power Sources 249 (2014) 405-413.

[40] D. Marrero-López, R. Romero, F. Martín, J.R. Ramos-Barrado, Effect of the de-

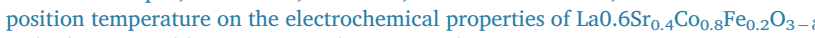
cathode prepared by conventional spray-pyrolysis, J. Power Sources 255 (2014) 308-317.

[41] X'Pert HighScore Plus, Version 3.0e, PANalytical BV, Amelo, The Netherlands, 2012.

[42] A.C. Larson, R.B. von Dreele, G.S.A.S. Program, Los Alamos National Lab Rep. No. LA-UR-86748, (1994).

[43] B. Moreno, R. Fernández-González, J.R. Jurado, A. Makradi, P. Nuñez, E. Chinarro, Fabrication and characterization of ceria-based buffer layers for solid oxide fuel cells, Int. J. Hyd. Energy 39 (2014) 5433-5439.

[44] Inorganic Crystal Structure Database, ICSD, 2014 pp. v2014-01.

[45] D. Johnson, ZView: A Software Program for IES Analysis, Version 2.8, Scribner Associates, Inc., Southern Pines, NC, 2002.

[46] L. dos Santos-Gómez, J.M. Porras-Vázquez, E.R. Losilla, F. Martín, J.R. Ramos-

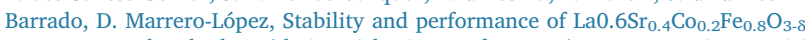
nanostructured cathodes with $\mathrm{Ce}_{0.8} \mathrm{Gd}_{0.2} \mathrm{O}_{1.9}$ surface coating, J. Power Sources 347 (2017) 178-185.

[47] Y. Li, W. Zhang, Y. Zheng, J. Chen, B. Yu, Y. Chen, M. Liu, Controlling cation segregation in perovskite-based electrodes for high electro-catalytic activity and durability, Chem. Soc. Rev. 46 (2017) 6345-6378.

[48] H. Wang, K.J. Yakal-Kremski, T. Yeh, G.M. Rupp, A. Limbeck, J. Fleig, S.A. Barnet, Mechanisms of performance degradation of $(\mathrm{La}, \mathrm{Sr})(\mathrm{Co}, \mathrm{Fe}) \mathrm{O}_{3-\delta}$ solid oxide fuel cell cathodes, J. Electrochem. Soc. 163 (2016) F581-F585.

[49] S.J. Benson, D. Waller, J.A. Kilner, Degradation of $\mathrm{La}_{0.6} \mathrm{Sr}_{0.4} \mathrm{Fe}_{0.8} \mathrm{Co}_{0.2} \mathrm{O}_{3-\delta}$ in carbon dioxide and water atmospheres, J. Electrochem. Soc. 146 (1999) 1305-1309.

[50] L. Agun, H.A. Rahman, S. Ahmad, A. Muchtar, Durability and stability of LSCF composite cathode for intermediate-low temperature of solid oxide fuel cell (IT-LT SOFC): Short review, Adv. Mat. Res. 893 (2014) 732-737.

[51] H. Xu, H. Zhang, A. Chu, An investigation of oxygen reduction mechanism in nanosized LSCF-SDC composite cathodes, Int. J. Hyd. Energy 41 (2016) 22415-22442.

[52] E. Perry Murray, M.J. Sever, S.A. Barnett, Electrochemical performance of (La,Sr) $(\mathrm{Co}, \mathrm{Fe}) \mathrm{O}_{3}-(\mathrm{Ce}, \mathrm{Gd}) \mathrm{O}_{3}$ composite cathodes, Solid State Ionics 148 (2002) 27-34.

[53] H.-N. Im, M.-B. Choi, B. Singh, D.-K. Lim, S.-J. Song, Investigation of oxygen reduction reaction on $\mathrm{La} 0.1 \mathrm{Sr}_{0.9} \mathrm{Co}_{0.8} \mathrm{Fe}_{0.2} \mathrm{O}_{3-\delta}$ electrode by electrochemical 
impedance spectroscopy, J. Electrochem. Soc. 162 (2015) F728-F735.

[54] Y. Gong, R.L. Patel, X. Liang, D. Palacio, X. Song, J.B. Goodenough, K. Huang, Atomic layer deposition functionalized composite SOFC cathode

$\mathrm{La}_{0.6} \mathrm{Sr}_{0.4} \mathrm{Fe}_{0.8} \mathrm{Co}_{0.2} \mathrm{O}_{3-\delta}-\mathrm{Gd}_{0.2} \mathrm{Ce}_{0.8} \mathrm{O}_{1.9}$ : Enhanced long-term stability, Chem. Mater. 25 (2013) 4224-4231.

[55] Z. Cai, M. Kubicek, J. Fleig, B. Yildiz, Chemical heterogeneities on $\mathrm{La}_{0.6} \mathrm{Sr}_{0.4} \mathrm{CoO}_{3-\delta}$ thin films-correlations to cathode surface activity and stability, Chem. Mater. 24 (2012) 1116-1127.

[56] T.T. Fister, D.D. Fong, J.A. Eastman, P.M. Baldo, M.J. Highland, P.H. Fuoss, K.R. Balasubramaniam, J.C. Meador, P.A. Salvador, In situ characterization of strontium surface segregation in epitaxial $\mathrm{La} 0.7 \mathrm{Sr}_{0.3} \mathrm{MnO}_{3}$ thin films as a function of oxygen partial pressure, Appl. Phys. Lett. 93 (2008) 1519041-1519043. 